\title{
Barajların Çevresel Etkilerinin Zamansal ve Mekansal Olarak Uzaktan Algılama İle Değerlendirilmesi: Atatürk Barajı Örneği
}

\author{
Gülcan SARP ${ }^{1 *}$, Arzu ERENER ${ }^{2}$ \\ ${ }^{1}$ Kocaeli Üniversitesi, Mühendislik Fakültesi, Harita Mühendisliği Bölümü, Kocaeli \\ (arzu.erener@kocaeli.edu.tr) \\ ${ }^{2}$ Süleyman Demirel Üniversitesi, Fen Edebiyat Fakültesi, Çoğrafya Bölümü, Isparta \\ (gulcansarp@sdu.edu.tr)
}

\begin{abstract}
$\ddot{O} \mathbf{z}$
Barajlar ülkenin enerji üretiminin en doğal ve en ucuz yoludur. Barajlar inşa etmek, ucuz enerji üretimi, rekrasyon olanaklarını artırması, tarımsal arazilerin sulanması, şehir şebekeleri için gerekli olan suyu sağlaması ve taşkın kontrolü açısından büyük önem taşırlar. Bununla birlikte, alansal olarak çok büyük barajlar, havadaki nem oranını artırarak bulunduğu bölgenin iklimini ve ekolojik dengesini değiştirmektedirler. Bu çalışmada Atatürk Baraj gölünün 1992 ve 2016 yılları arasında bölge üzerindeki çevresel etkileri uydu görüntüleri ve uzaktan algılama teknikleri kullanılarak ortaya konulmaya çalışılmıştır. Çalışmada 1992, 1998, 2006 ve 2016 yıllarına ait Landsat 4,5 TM ve Landsat 8 OLI-TIRS uydularına ait görüntüler kullanılmıştır. Çalışma alanına ait bitki alanları, toprağa göre ayarlanmış bitki örtüsü indeksi (SAVI) ve yüzey nemliliği normalleștirilmiş nem fark indeksi (NDMI) kullanılarak, yıllara ait yüzey sıcaklık dağılımları (YSD) ise Landsat 4, 5 TM, ve Landsat 8 OLI-TIRS uydularının termal kızıl ötesi (TIR) bandları kullanılarak elde edilmiştir. 1992, 1998, 2006 ve 2016 yıllarında meydana gelen bitki alanları, yüzey nemliliği ve yüzey sıcaklık dağılımları arasındaki ilişski rastlantısal olarak seçilmiş 500 noktada eşit aralıklı ve oran ölçekte Pearson korelasyon katsayısı kullanılarak test edilmiştir.
\end{abstract}

\section{SPATIOTEMPORAL EVALUATION OF ENVIRONMENTAL EFFECTS OF DAMS WITH REMOTE SENSING TECHNIQUES: ATATÜRK DAM CASE}

\begin{abstract}
Dams are the most natural and cheapest way of energy production in the country. Dam construction has great importance interms of cheap energy production, increasing recreational opportunities, watering of agricultural land, water supply for city networks and flood control. However, very large dams increase the humidity of the air and change the climate and ecological balance of the region. In this study, the environmental impacts of the Atatürk Dam Lake were evaluated between 1992 and 2016 years by using satellite imagery and remote sensing techniques. In the study Landsat 4,5 TM and Landsat 8 OLI satellite images were used. Vegetated areas and surface moisture 2016 were extracted from satellite imges by using Soil Adjusted Vegetation Index (SAVI) and Normalized Difference Moisture Index (NDMI) respectively. On the other hand, surface temperature distributions for the mentioned years were determined using the thermal infrared (TIR) bands of Landsat 4, 5 TM, and Landsat 8 OLI-TIRS satellites. The relationship among vegetated areas, surface moisture and surface temperature for the 1992, 1998, 2006 and 2016 years were investigated for randomly sellected 500 points by using Pearson correlation coefficient that were equally spaced and proportionally scaled.
\end{abstract}

Keywords: YSD, SAVI, NDMI, Image Processing, Landsat

* Sorumlu Yazar 


\section{GİRIŞ}

Akarsular yeryüzünü şekillendirici en önemli etkenlerden biridir. Dünyanın her tarafinda akarsulardan en yoğun şekilde faydalanma şekli olarak baraj yapımı, gerek akarsuların çevrede meydana getirebileceği olumsuz etkileri azaltmak ve gerekse enerji üretimi ile beraber sulamayı kontrol altına alarak tarımsal üretimi arttırmak bakımından önem kazanmıştır (Sönmez, M.E., 2012). Bu yoğun kullanım ciddi çevre sorunlarını da beraberinde getirmektedir. Bir akarsu üzerindeki baraj sayısı ve büyüklüğündeki artış doğal tahribatın büyüklüğü ile doğru orantılıdır. Baraj yapımından kaynaklanan bu olumsuzluklar genel olarak arazi potansiyelinin doğru değerlendirilmemesine bağlı olarak ortaya çıkmaktadır (Bayrakdar, 2004). Baraj göllerinin bulundukları bölgenin iklim özelliklerini etkileyerek değiştirdiği ve bölgeye farklı bir iklim yapısı kazandırdığı da bilinmektedir (Güldal ve Ağıralioğlu, 1994; Kadıŏlu ve diğerleri, 1994).

Geçmiş yıllardan güzümüze kadar barajlarla ilgili olarak bölge iklimi ve çevresel etkileri üzerine farklı çalışmalar yapılmıştır. Bacanlı ve Tuğrul (2016), yaptıkları çalışmada, Vali Recep Yazıcıŏlu Gökpınar Baraj Gölü’nün Denizli ili iklimine etkisi araştırılmıştır. Çalışmada Denizli ili meteoroloji istasyonundan alınmış maksimum, minimum ve ortalama sıcaklık, rüzgâr hızı, yağış ve buharlaşma verileri kullanılmıştır. Baraj yapılmadan önceki ve sonraki verilerdeki mutlak değişimler incelenmiş ve çalışma sonucunda baraj yapımından sonra bölgede maksimum, minimum ve ortalama sıcaklıklarda tüm aylarda bir artış gözlendiği sonucuna varmışlardır. Bulut ve diğerleri (2006), Atatürk Barajı`nın bölge iklimi üzerindeki etkisini araştırmışlar bu çalışmada baraj gölüne yakın iki il merkezindeki meteorolojik parametrelerin trend analizlerini yapmışlardır. Çalışma sonucunda bölgede sıcaklık ve bağıl nemde artış trendi olduğu, toplam yağışta önemli bir değişimin olmadığı ve rüzgâr hızında azalma olduğu sonucuna varılmıştır. Yeşilata ve diğerleri (2004), Atatürk Baraj Gölü’nün bölge iklimi üzerine etkisini, Şanlıurfa ve Adiyaman illerinin 30 y1llk (1972-2001) meteorolojik verileri yardımıyla araştırmışlardır. Çalışmada baraj yapımı sonrasında her iki il için; yılın büyük bir bölümünde, hem sicaklık ve hem de nem değerlerinde artış olduğunu gözlemlemişlerdir. Nagarajan (2000), Hindistan`daki Dudhganga Barajı̀nın arazi kullanımı üzerindeki çevresel etkilerini baraj yapımı öncesi, sırası ve sonrasına ait SPOT ve IRS görüntülerini kullanarak görüntü işleme yöntemleri ile analiz etmiş baraj yapımının arazi kullanımı üzerine olumsuz etkilerinin olduğunu belirtmiştir. Yeşilnaçar ve Gülșen (1999) Atatürk Baraj Gölü nün yöre ikliminde meydana getirebileceği değişimleri tespit etmek amaciyla yöre ikliminin karakteristik özellikleri ile barajdan önce ve sonraki meteorolojik parametrelerdeki değişimleri değerlendirilmiştir. Çalışma sonucunda Şanlıurfa ilinin karakteristik iklim özellikleri bölge iklimi ile karşılaştırılmış, bölge iklimi parametreleri ortalamasına göre; sicaklığın daha yüksek, yağışın az, güneşlenme süresinin en fazla ve iklimin çok kurak karakterde olduğu görülmüştür. Güldal ve Ağıralioğlu (1994), baraj haznelerinin çevresel etkileri kapsamında Keban Barajı'nı incelemiş, kışın sıcaklıkta artış, yazın nemde yükselmeler olduğunu tespit etmişlerdir.

$\mathrm{Bu}$ çalışmada ise yapılan diğer çalışmalardan farklı olarak Atatürk Baraj gölünün 1992 ve 2016 yılları arasında bölge üzerindeki çevresel etkileri uydu görüntüleri ve uzaktan algilama teknikleri kullanılarak ortaya konulmaya çalışılmıştır. Çalışmada Landsat 4,5 TM ve Landsat 8 OLI-TIRS uydularına ait görüntüler kullanılmıştır. 1992, 1998, 2006 ve 2016 yıllarında çalışma alanına ait bitki alanları, toprağa göre ayarlanmış bitki örtüsü indeksi (SAVI), yüzey nemliliği normalleştirilmiş nem fark indeksi (NDMI) kullanılarak ve yıllara ait yüzey sıcaklık dağ $11 ı$ ları da Landsat 4,5 TM, ve Landsat 8 OLI-TIRS uydularının termal kızıl ötesi (TIR)

\footnotetext{
* Sorumlu Yazar
} 
bandları kullanılarak belirlenmiştir. 1992, 1998, 2006 ve 2016 y1llarında meydana gelen bitki alanları, yüzey nemliliği ve yüzey sıcaklık dağılımları arasındaki ilişki rastlantısal olarak seçilmiş 500 noktada eşit aralıklı ve oran ölçekte Pearson korelasyon katsayısı kullanılarak test edilmiştir.

\section{2. ÇALIŞMA ALANI VE DATA}

Atatürk Barajı, Adıyaman ve Şanlıurfa illeri arasında, Firat Nehri üzerinde kurulu olup, enerji ve sulama amaçlı yapılmış olan bir barajdır (Şekil 1). Atatürk Baraj1 ve Hidroelektrik Santrali Güneydoğu Anadolu Projesinin (GAP) önemli aşamalarından biri olup; sulama, enerji üretimi vb. amaçlarla yapımına 3 Kasım 1983 tarihinde başlanılmıştır. Atatürk Barajı rezervuarı 1990 yılından itibaren dolmaya başlamış, bugün normal işletme seviyesine gelmiştir (Yeşilnaçar ve Gülşen, 1999). Atatürk Baraj
Gölü, $180 \mathrm{~km}$ uzunluğu, $48.7 \mathrm{~km} 3$ hacmi ve 817 km2 yüzölçümüyle Türkiye' nin 3. büyük gölü konumundadır (DSI, 2016).
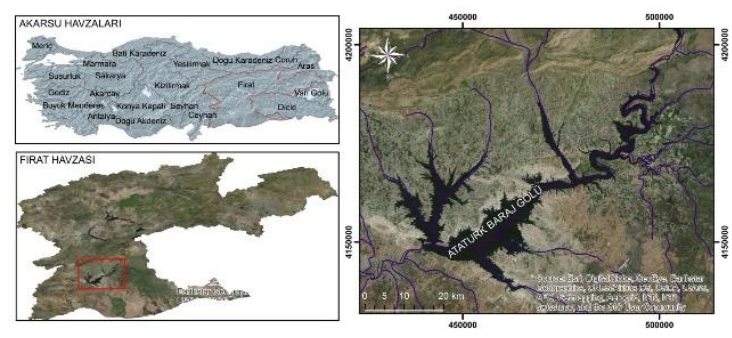

Şekil 1: Çalışma alanı ve Atatürk Barajı konum haritas1

$\mathrm{Bu}$ çalışmada USGIS tarafindan sağlanan bulutluluk oranı düşük 1992 yılına ait Landsat 4 TM 1998, 2000 yıllarına ait Landsat 5 TM ve 2016 y1lına ait Landsat 8 OLI-TIRS uydu görüntüleri kullanılmış olup kullanılan uydu görüntülerine ait zamansal bilgiler ve yalanc1 renk kombinasyonları Tablo 1 ve Şekil 2 de verilmiştir.
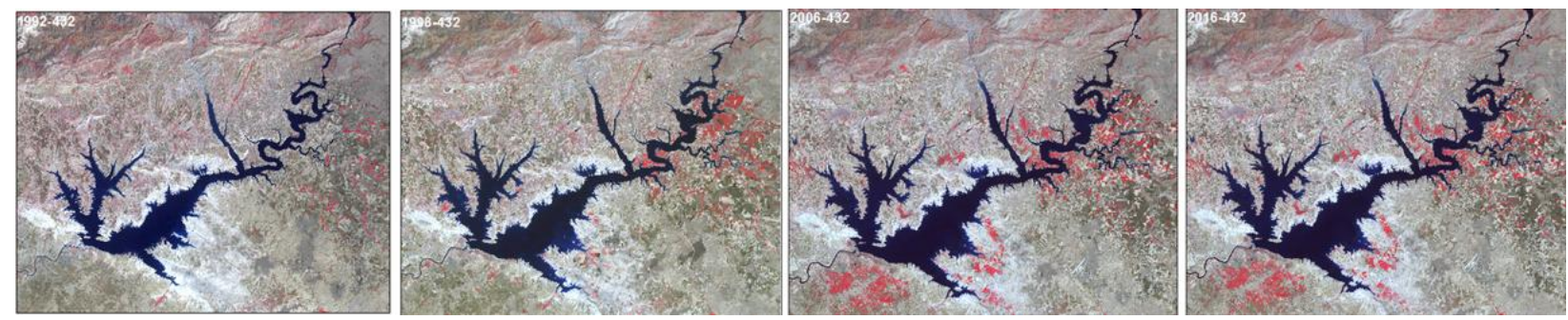

Şekil 2: 1992, 1998, 2006 ve 2016 Landsat 4-5 TM ve Landsat 8 OLI-TIRS görüntülerine ait yalanc1 renk kombinasyonları (USGS, 2013).

Tablo 1: Kullanılan uydu görüntüleri ve görüntülere ait bilgiler

\begin{tabular}{|c|c|c|c|c|c|}
\hline $\begin{array}{l}\text { Uydu ve Çekim } \\
\text { Tarihi }\end{array}$ & Sensör Tipi & $\begin{array}{l}\text { Spectral } \\
\text { Aralık }\end{array}$ & $\begin{array}{l}\text { Bant } \\
\text { Numaraları }\end{array}$ & $\begin{array}{l}\text { Çekim } \\
\text { Alanı } \\
\text { Boyutu }\end{array}$ & $\begin{array}{l}\text { Hücre } \\
\text { Çözünürlüğü }\end{array}$ \\
\hline $\begin{array}{l}\text { L4 TM (28-08-1992) } \\
\text { L5 TM (21-08-1998) }\end{array}$ & Multispektral & $\begin{array}{l}0.450-2.35 \\
\mu \mathrm{m}\end{array}$ & $1,2,3,4,5,7$ & $170 \times 183 \mathrm{~km}$ & $30 \mathrm{~m}$ \\
\hline L5 TM (11-08-2006) & $\begin{array}{l}\text { Termal } \\
\text { ötesi }\end{array}$ & $\begin{array}{l}10.40- \\
12.50 \mu \mathrm{m}\end{array}$ & 6 & & $120 \mathrm{~m} *(30)$ \\
\hline \multirow{3}{*}{$\begin{array}{l}\text { L8 OLI } \\
(06-08-2016)\end{array}$} & Multispektral & $0.433-1.39$ & $1,2,3,4,5,6,7,9$ & $180 \times 185$ & $30 \mathrm{~m}$ \\
\hline & $\begin{array}{l}\text { Termal } \quad \text { Kizıl } \\
\text { ötesi }\end{array}$ & $10.6-12.5$ & 10,11 & & $100 \mathrm{~m} * *(30)$ \\
\hline & Pankromatik & $0.50-0.68$ & 8 & & $15 \mathrm{~m}$ \\
\hline
\end{tabular}

* L4-5 TM 6. Bant1 120 m mekânsal çözünürlükte elde edilir, fakat ürünler 30 m mekânsal çözünürlüğe örneklenir.

**L8 OLI TIRS bandı 100 m. mekânsal çözünürlükte elde edilir, fakat ürünler 30 m mekânsal çözünürlüğe örneklenir. 


\section{YÖNTEM}

Çalışmada iki farklı aşamadan meydana gelmiştir. İlk aşama 1992-1998-2006 ve 2016 yıllarında çalışma alanına ait yüzey sıcaklık değerlerinin uydu görüntülerinin termal kızıl ötesi (TIR) bandları kullanılarak belirlenmesi, SAVI kullanılarak alana ait bitki örtüsünün belirlenmesi, kuraklık takibi ve bitki örtüsü alanlarında nemlilik değişiminin NDMI kullanılarak belirlenmesini içermektedir. Çalışmanın ikinci aşaması ise 1992-19982006 ve 2016 yıllarında meydana gelen bitki alanları, yüzey nemliliği ve yüzey sıcaklık dağılımları arasındaki ilişkiyi rastlantısal olarak seçilmiş 500 noktada eşit aralıklı ve oran ölçekte ilişkinin ölçülmesi Pearson korelasyon katsayıs1 kullanilarak test edilmesidir. Çalışmaya ait iş akış şeması Şekil 3'de sunulmaktadır.

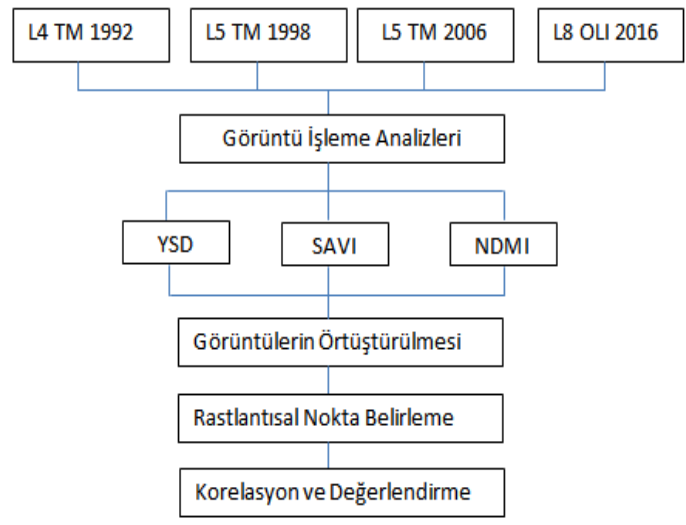

Şekil 3: Çalışmaya ait iş akış şeması

\subsection{Yüzey sıcaklık değerlerinin (YSD) termal kızl ötesi (TIR) band kullanılarak belirlenmesi}

$\mathrm{Bu}$ çalışmada yüzey sıcaklık değerleri Landsat 4, 5 TM ve Landsat 8 OLI-TIRS uydularının TIR bandları kullanılarak belirlenmiştir. Yüzey sıcaklık değerlerinin Landsat uydu görüntüsünden belirlenebilmesi için görüntüler GeoTIFF formatında meta verileri ile birlikte USGS web sayfasindan indirilmiştir. İlk olarak görüntüde bulunan sayısal değerler (DN) formül (1) kullanılarak spektral radyans değerlerine dönüştürülmüştür.

$$
L_{\Lambda}=\frac{\left(\operatorname{LMax}_{\Lambda}-\operatorname{LMin}_{\Lambda}\right)}{\left(Q \operatorname{CalMax} x_{\Lambda}-Q \text { CalMin }\right)} X(D N-Q \text { CalMin })+L \operatorname{Min}_{\Lambda}
$$

$\mathrm{Bu}$ formülde ; $\mathrm{L} \Lambda$ spectral radyans değerini, DN hücre değerlerini, Lmin ve Lmax ise termal bandtaki minimum ve maksimum spectral yansıma değerlerini, QCalMin ve QCalMax, kalibre edilmiş minimum ve maximum hücre değerlerini göstermektedir (NASA, 2011; Chander ve Markham, 2003).

Bir sonraki aşamada TIR bandtan elde edilen radyans parlaklık değerleri formül (2) kullanılarak sıcaklık değerlerine dönüştürülür.

$$
T=\frac{K_{2}}{\ln \left(\frac{K_{1}}{L_{K}}\right)+1}
$$

$\mathrm{Bu}$ förmülde $\mathrm{T}$ Kelvin cinsinden sicaklık değeri, $\mathrm{K} 1$ ve $\mathrm{K} 2$ değerleri ise TIR bandının kalibrasyon sabitleri olup Landsat 4- 5 TM, Landsat 7 ETM ve Landsat 8 OLI-TIRS için bu değerler Tablo 2` de verilmiştir.

Tablo 2: Landat uydularının kalibrasyon sabitleri (USGS, 2013)

\begin{tabular}{|l|l|l|l|l|}
\hline & & & \multicolumn{2}{|l|}{$\begin{array}{l}\text { Landsat } \\
\text { TIRS }\end{array}$} \\
\cline { 4 - 6 } & \multirow{2}{*}{$\begin{array}{l}\text { Landsat } \\
4,5-\mathrm{T} M\end{array}$} & $\begin{array}{l}\text { Landsat } \\
7-\mathrm{ETM}\end{array}$ & $\begin{array}{l}\text { Band } \\
10\end{array}$ & $\begin{array}{l}\text { Band } \\
11\end{array}$ \\
\hline K1 & 607,76 & 666.09 & 774.89 & 1321.08 \\
\hline K2 & 1260,56 & 1282.71 & 480.89 & 1201.14 \\
\hline
\end{tabular}

Son aşamada ise Kelvin formatında elde edilmiş yüzey sıcaklık değerleri formül (3) kullanılarak derece formatına dönüştürülür.

$T\left({ }^{\circ} \mathrm{C}\right)=T-273(K)$

\subsection{Toprağa göre ayarlanmış bitki örtüsü indeksi (SAVI)}

Uydu görüntülerinden, görüntü işleme yöntemleri kullanılarak bitki örtüsünün belirlenmesi için farklı indeksler geliştirilmiştir. $\mathrm{Bu}$ indekslerin en yaygın olanı, kırmızı ve kızılötesi bitki yansımalarını 
veya oranlardaki parlaklıkları kullanmaktadır (Tucker, 1979). Bitki örtüsünün üzerinde bulunduğu toprak, bitki indeksi hesaplamalarında önemli bir etkiye sahiptir. Koyu renkli topraklar üzerinde bulunan bitkisel alanlarda uygulanan bitki indeks oranları $(\mathrm{RVI}=$ Yakın Kızıl Ötesi/Kırmızı) veya normalize edilmiş bitki fark indeksleri (NDVI =( Yakın Kızıl Ötesi-Kırmızı) / (Yakın Kızıl Ötesi+Kırmızı)) yüksek indeks değerleri vermektedir (Colwell, 1974; Elvidge ve Lyon, 1985; Huete, 1987). Bitki örtüsünün \%40` dan daha az olduğu ve toprak yüzeyinin açığa çıktığı alanlarda, kırmızı ve yakın kızı̈ötesi spektrumdaki 1şığın yansıması bitki indeksi değerlerini etkilemektedir. Bu durum kırmızı ve yakın kızı̈ötesi dalga boylarındaki farklı 1şık miktarlarını yansıtan farklı parlaklık değerlerine sahip toprak türleri arasında karşılaştırmalar yapıldığında bir problem olarak görülmektedir. $\mathrm{Bu}$ nedenden dolayı (SAVI), bitki örtüsünün az olduğu alanlarda toprak parlaklığının etkisini düzeltmek için normalize edilmiş bitki fark indeksinin (NDVI) bir modifikasyonu olarak geliştirilmiştir. SAVI, NDVI ye benzer bir şekilde formüle edilmiş olup NDVI den fark1 toprak parlaklık düzeltme faktörünün eklenmiş olmasıdır.

Landsat 4, 5 TM, sensörleri için SAVI formül (4) Landsat 8 OLI-TIRS sensörü için ise formül (5) kullanılarak belirlenir.

$$
\begin{aligned}
& S_{S A V I} I_{L 4-5}=\frac{\text { (Band 4-Band 3) }}{(\text { Band 4 }+ \text { Band 3 }+L)} *(1+L) \\
& \text { SAVI }_{L 8}=\frac{\text { (Band 5 -Band 4) }}{(\text { Band 5 +Band 4+L) }} *(1+L)
\end{aligned}
$$

$\mathrm{Bu}$ formülde $\mathrm{L}$ değeri toprak parlaklık düzeltme faktörünü ifade etmektedir. L değeri yeşil bitki örtüsünün miktarına ve yayılımına göre değişmekte olup: bitki örtüsünün çok yoğun olduğu alanlarda " 0 ", yeşil bitki örtüsünün olmadığı alanlarda "1" değerini alır. Genel olarak $\mathrm{L}=0.5$ değeri çoğu durumda iyi çalışır ve kullanılan varsayılan değerdir. $\mathrm{L}=0$ durumunda SAVI sonucu NDVI sonucuna eşdeğerdir.

\subsection{Normalleştirilmiş nem fark indeksi (NDMI)}

Normalleştirilmiş nem fark indeksi (NDMI), diğer bitki örtüsü indeksleri (NDVI ve / veya AVI) ile birlikte kullanılan ve vejetasyon nemi ile ilişkili olan sayısal bir göstergedir (Hardisky ve diğerleri, 1983). NDMI, bitki örtüsü alanlarındaki nem değişimlerini belirlemek için için yakın kızıl ötesi ve kısa dalga kızıl ötesi spektral bantları kullanır. Kuraklık takibi ve bitki örtüsü alanlarında nemlilik değişiminin belirlenmesi için NDMI kullanılmaktadır

NDMI, Landsat 4, 5 TM sensörleri için formül (6) Landsat 8 OLI-TIRS sensörü için ise formül (7) kullanılarak belirlenir.

$$
\begin{aligned}
& N D M I_{L 4-5}=\frac{(\text { Band } 4-\text { Band } 5)}{(\text { Band } 4+\text { Band } 5)} \\
& N D M I_{L 8}=\frac{(\text { Band } 5-\text { Band } 6)}{(\text { Band } 5+\text { Band } 6)}
\end{aligned}
$$

\subsection{Pearson`in Korelasyon Katsayısı}

Pearson`in Korelasyon Katsayısı (Pearson's correlation coefficient) İngiliz matematikçi Karl Pearson (1857-1936) tarafindan ortaya konmuştur. Korelasyon katsayısı, bağımsız değişkenler arasındaki ilişkinin yönü ve büyüklüğünü belirten katsayıdır. Bu katsayı, $(-1)$ ile $(+1)$ arasında bir değer alır. Pozitif değerler iki değişkene ait yüksek değerlerin yüksek değerler ile düşük değerlerinde düşük değerlerle birlikte olduğunu gösterirken; negatif değerler ise iki değişkene ait yüksek ve düşük değerlerin birlikte olduğu ters yönlü bir doğrusal ilişkiyi belirtir.

Pearson`ın korelasyon katsayısı, $r$ formül (8) kullanılarak belirlenir;

$r=\frac{\sum_{i=1}^{n}\left(x_{i}-\vec{x}\right)\left(y_{i}-\bar{y}\right)}{(n-1) s_{x} s_{y}}$

$\mathrm{Bu}$ formülde $\mathrm{x}_{\mathrm{i}}$, $\mathrm{i}$ gözleminin $\mathrm{x}$ değişkenine ait değerini; $\bar{x}, \mathrm{x}$ değişkenine ait örneklem ortalamasını; $S_{x}, x$ değişkenine ait örneklem standart sapmasını; $y_{i}, \quad i$ gözleminin $y$ değişkenine ait değerini; $\bar{y}, \mathrm{y}$ değişkenine ait 
örneklem ortalamasını; $S_{y}$, y değişkenine ait örneklem standart sapmasını ve $\mathrm{n}$ gözlem sayısını göstermektedir (Çubukçu K.M., 2015).

Pearson`ın korelasyon katsayısının 1`e yakınlaşması bağımsız değişkenler arasındaki güçlü doğrusal pozitif ilişkiyi, korelasyon katsayısının -1`e yakınlaşması bağımsız değişkenler arasındaki güçlü doğrusal negatif ilişkiyi, değerin 0 olması bağımsız değişkenler arasında bir ilişkinin olmadığını gösterir (Mendelhall ve diğerleri, 1986)

\section{BULGULAR VE TARTIŞMALAR}

Landsat TM 4,5 ve OLI-TIRS uydularının TIR bandları kullanılarak elde edilen 1992, 1998, 2006 ve 2016 yıllarına ait yüzey sıcaklık dağılımları ve bu dağılımlara ait histogramlar Şekil 4 ve $5^{\prime}$ de verilmiştir. Çalışma alanına ait yüzey sıcaklık dağılımlarının yıllara göre değişimine bakıldığı zaman 1992 ve 1998 yıllarında baraj göl alanının güney batısındaki sicaklık değerlerinin 2006 ve 2016 yıllarına göre oldukça yüksek olduğu gözlemlenmektedir. Bunun başlica nedeni baraj göl yüzey alanında meydana gelen artma ve göl alanının güney batısındaki bitki yoğunluğundaki artma olarak yorumlanabilinir.
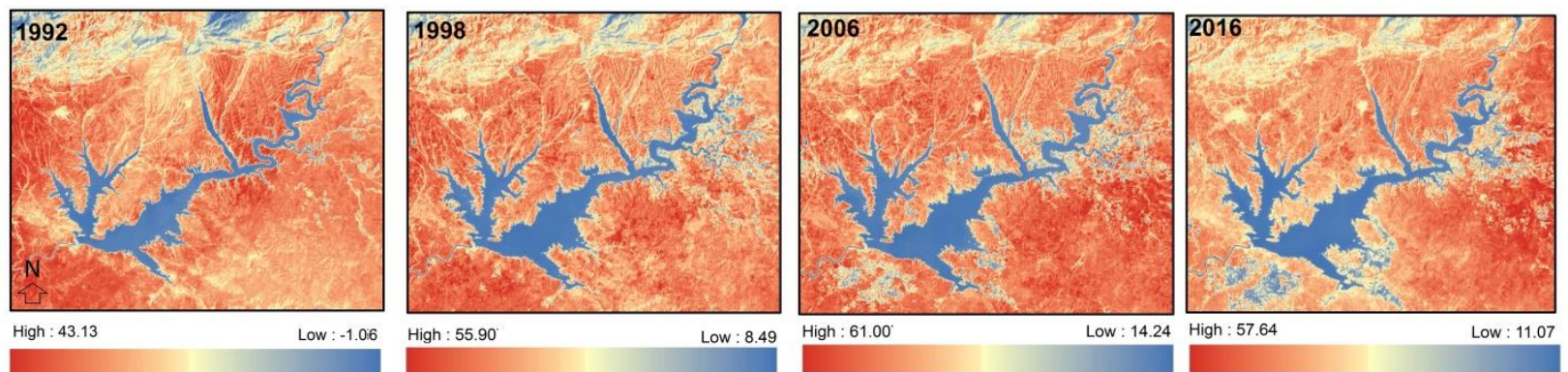

Şekil 4: 1992, 1998, 2006 ve 2016 Landsat 4-5 TM ve Landsat 8 OLI-TIRS görüntüleri termal kızılötesi bandından elde edilen yüzey sıcaklık dağılımları
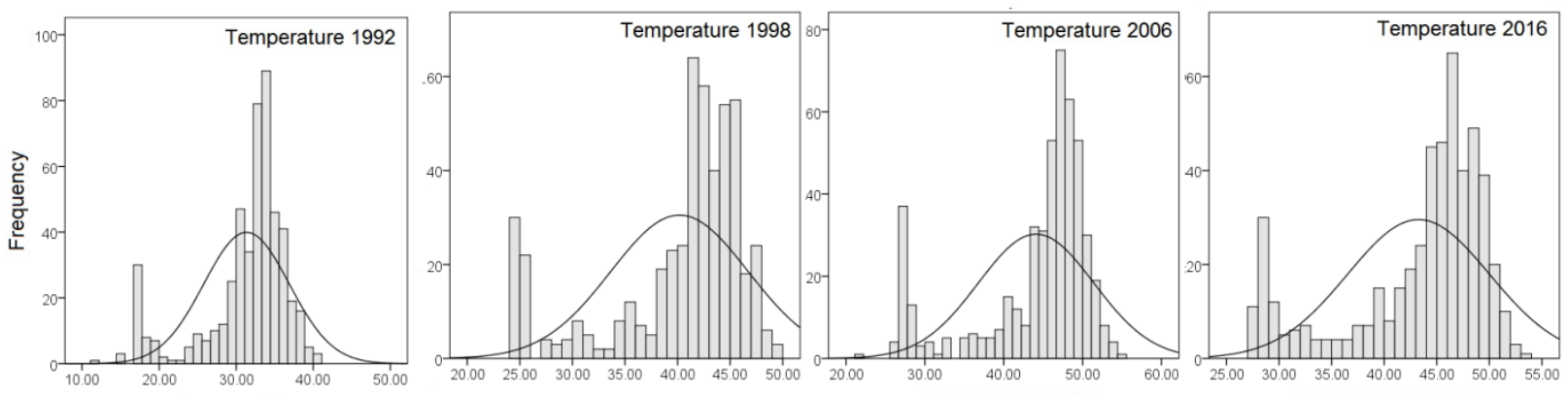

Şekil 5: 1992, 1998, 2006 ve 2016 Landsat 4-5 TM ve Landsat 8 OLI-TIRS görüntüleri termal kızılötesi bandından elde edilen yüzey sıcaklık dağılımlarına ait histogramlar

2016 y1lında gözlemlenen en düşük ve en yüksek sicaklık 27.52 Co ve 53.55 Co ortalama sicaklik ise 43.26 Co olarak belirlenmiştir. 2006 yılınada yüzey sıcaklık değerlerinin 2016 y1liyla benzerlik gösterdiği belirlenmiştir. 2006 yılında en düşük ve en yüksek sicaklık 21.94 Co ve 55.21 Co ortalama sicaklık ise 44.10 Co olarak belirlenmiştir. 1998 y1lında ise en düşük ve en yüksek sicaklık değerleri 24.12 Co ve 49.93 Co ortalama sicaklik ise 40.18 Co dir. 2016, 2006, 1998 ve 1992 yılları yüzey sıcaklık dağılımları karşılaştırıldığında 1992 yılındaki en düşük $(12.10 \mathrm{Co})$, en yüksek $(40.87 \mathrm{Co})$ ve ortalama $(31.33 \mathrm{Co})$ sicaklık değerlerinin diğer yıllara göre oldukça düşük olduğu 
gözlemlenmiştir. Bunun başlıca nedeni barajın yapımından itibaren baraj gölününde etkisi ile bölge havsının 1lımanlaşmasıdır (Tablo 3).

Tablo 3: Yüzey sıcaklık değerlerine ait istatistikler

\begin{tabular}{|l|l|l|l|l|}
\hline \multirow{2}{*}{ Yıllar } & \multicolumn{4}{|l|}{ Yüzey sicaklıklarl $\left(C^{0}\right)$} \\
\cline { 2 - 5 } & $\begin{array}{l}\text { Mini } \\
\text { mum }\end{array}$ & $\begin{array}{l}\text { Maksimu } \\
m\end{array}$ & $\begin{array}{l}\text { Ortalam } \\
a\end{array}$ & $\begin{array}{l}\text { Standart } \\
\text { Sapma }\end{array}$ \\
\hline 2016 & 27.52 & 53.55 & 43.26 & 6.74 \\
\hline 2006 & 21.94 & 55.21 & 44.10 & 7.32 \\
\hline 1998 & 24.12 & 49.93 & 40.18 & 6.53 \\
\hline 1992 & 12.10 & 40.87 & 31.33 & 5.54 \\
\hline
\end{tabular}

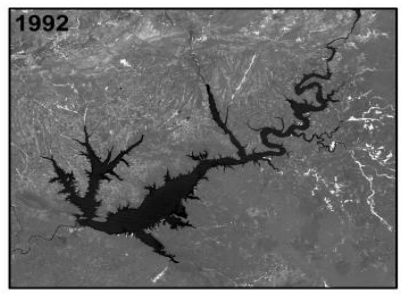

High : 0.96

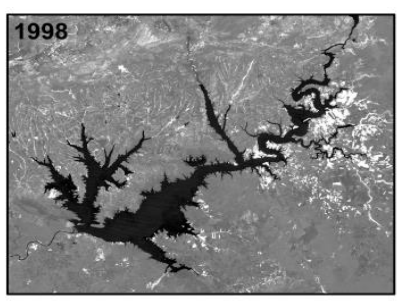

High : 1.09
1992, 1998, 2006 ve 2016 y1llarina ait SAVI değerleri ve histogramları Şekil 6 ve $7^{\prime}$ de verilmiştir. Şekil $6^{\prime}$ de açık renk tonları ile gösterilen yüksek SAVI değerleri bitki örtüsü yoğunluğunun fazla olduğu alanları, koyu renk tonlarıya gösterilen düşük SAVI değerleri ise bitki örtüsü yoğunluğunun az olduğu alanları göstermektedir. Çalışma alanına ait bitki örtüsü dağılımlarının yıllara göre değişimine bakıldığı zaman 1992 ve 1998 yıllarında baraj göl alanının güney batısındaki yoğunluğun 2006 ve 2016 yıllarına göre daha az olduğu gözlemlenmektedir. Bunun nedeni baraj gölü çevresindeki tarım alanlarının yoğunluğunun artması olarak yorumlanabilinir.

Şekil 6: 1992, 1998, 2006 ve 2016 Landsat 4-5 TM ve Landsat 8 OLI-TIRS görüntülerinden elde edilen toprağa göre ayarlanmış bitki örtüsü indeksi (SAVI) dağılımları
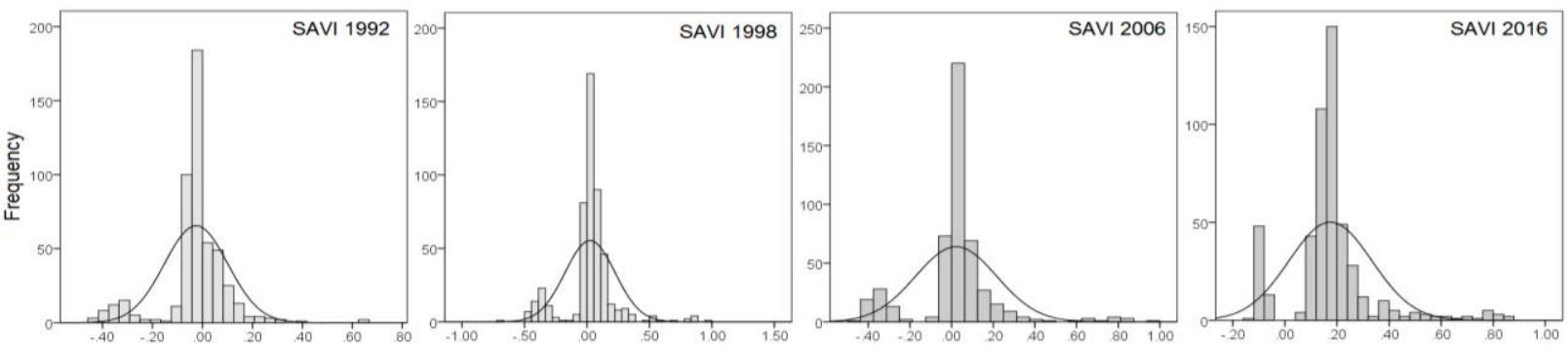

Şekil 7: 1992, 1998, 2006 ve 2016 Landsat 4-5 TM ve Landsat 8 OLI-TIRS görüntülerinden elde edilen toprağa göre ayarlanmış bitki örtüsü indeksi (SAVI) dağılımlarına ait histogramlar

değeri ise 0.02 dir. 1992 yllında ise ortalama

SAVI değerlerine ait istatistiklere bakıldığında 2016 yılında gözlemlenen en düşük ve en yüksek SAVI değerleri -0.13 ve 0.87 ortalama nemlilik değeri ise 0.17 olarak belirlenmiştir. 2006 y1lına gelindiğinde en düşük ve en yükssek SAVI değerlerinin -0.44 ve 0.96 olduğu ortalama SAVI değeri ise $0.02^{`}$ dir. 1998 yılında en düşük ve en yükssek SAVI değerleri -0.67 ve 0.99 ortalama SAVI SAVI değerinin -0.003 ile 2016, 2006, 1998 y1lları ortalama SAVI değerlerinden oldukça düşük olduğu en yüksek ortalama SAVI değerinin ise 2016 yılına ait olduğu belirlenmiştir. Bitki örtüsünde 1992 ve 2016 yılları arasındaki bu artışın nedeni olarak baraj gölününde etkisi ile bitki örtüsünün tarım alanlarının artışına bağlı olarak artması olarak gösterilebilinir (Tablo 4). 
Tablo 4: Toprağa göre ayarlanmış bitki örtüsü indeksi (SAVI) değerlerine ait istatistikler

\begin{tabular}{|l|l|l|l|l|}
\hline \multirow{2}{*}{ Yıllar } & \multicolumn{4}{|l}{$\begin{array}{l}\text { Toprağa göre ayarlanmış bitki örtüsü indeksi } \\
\text { (SAVI) }\end{array}$} \\
\cline { 2 - 5 } & Minimum & Maksimum & Ortalama & $\begin{array}{l}\text { Standart } \\
\text { Sapma }\end{array}$ \\
\hline 2016 & -0.13 & 0.87 & 0.17 & 0.16 \\
\hline 2006 & -0.44 & 0.96 & 0.02 & 0.19 \\
\hline 1998 & -0.67 & 0.99 & 0.02 & 0.20 \\
\hline 1992 & -0.42 & 0.66 & -0.03 & 0.13 \\
\hline
\end{tabular}
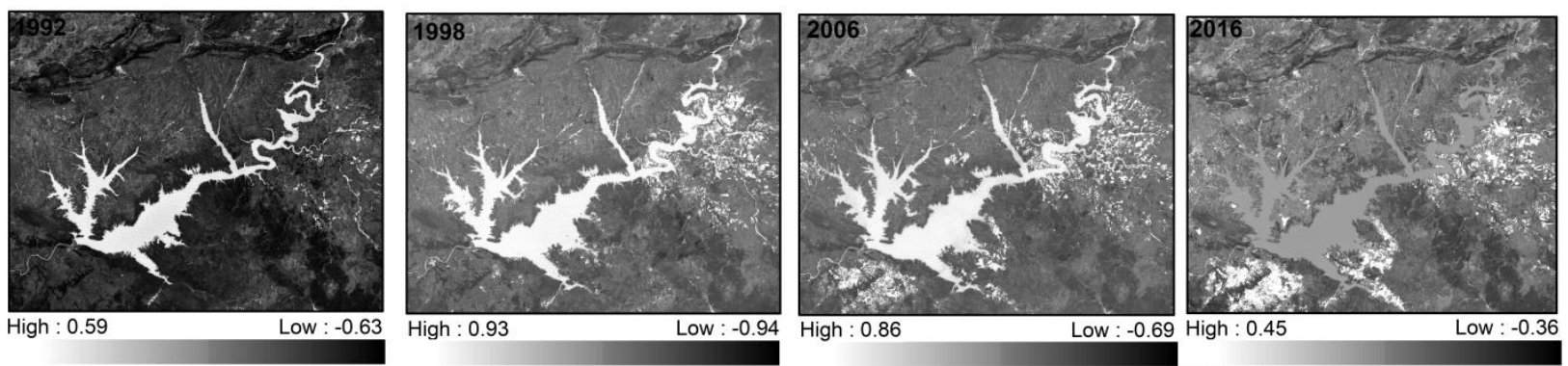

Uydu görüntülerinin yakın kızıl ötesi ve kısa dalga kızıl ötesi spektral bantları kullanılarak elde edilen 1992, 1998, 2006 ve 2016 y1llarına ait NDMI dağılımları ve bu dağılımlara ait histogramlar Şekil 8 ve 9`da sirasıyla verilmiştir. $\mathrm{Bu}$ şekle göre açık renk tonları yüksek nemlilik oranlarını koyu renk tonları ise düşük nemlilik oranlarını göstermektedir. Nemliliğin yüksek olduğu alanlar özellikle göl yüzey alanı ve çevresinde yoğunlaşmaktadır. Nemliliğin düşük olduğu alanlar ise özellikle baraj gölünün güney doğusunda yoğunlaşmıştır.

Çalışma alanındaki 1992, 1998, 2006 ve 2016 yıllarına ait NDMI değerlerinin histogramlarına bakıldığında 1992 yılındaki nemlilik dağ 1 lımının 1998, 2006 ve 2016 yıllarından farklı olduğu ve nemliliğin 2016 yılına doğru artış gösterdiği gözlenmiş̧tir (Şekil 8).

Şekil 8: 1992, 1998, 2006 ve 2016 Landsat 4-5 TM ve Landsat 8 OLI-TIRS görüntülerinden elde edilen Normalleştirilmiş nem fark indeksi (NDMI) dağılımları
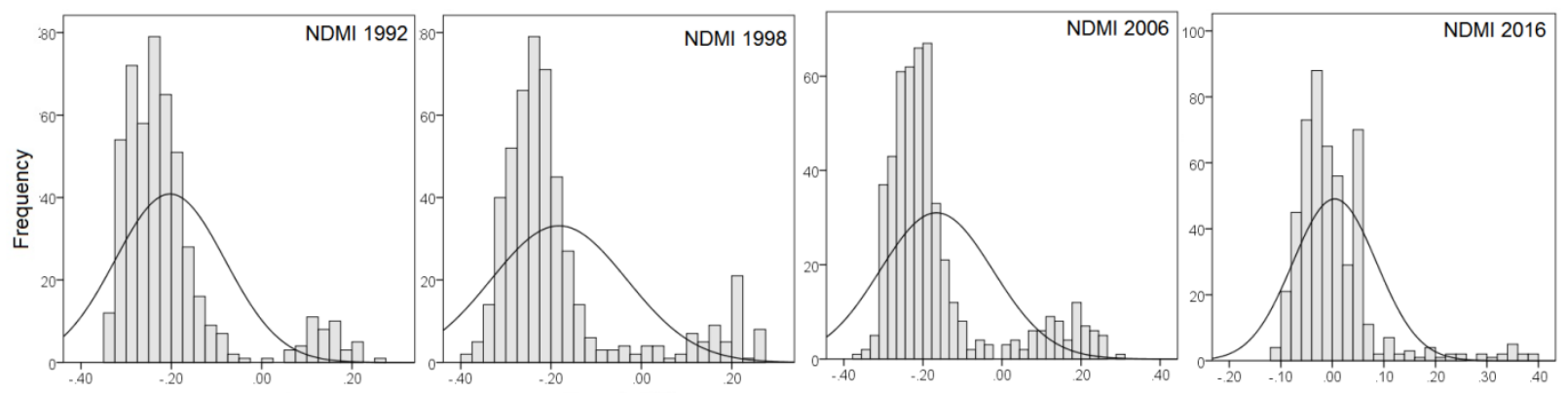

Şekil 9: 1992, 1998, 2006 ve 2016 Landsat 4-5 TM ve Landsat 8 OLI-TIRS görüntülerinden elde edilen Normalleştirilmiş nem fark indeksi (NDMI) dağılımlarına ait histogramlar

2016 y1lında gözlemlenen en düşük ve en yüksek NDMI değerleri -0.11 ve 0.40 ortalama nemlilik değeri ise 0.00 olarak belirlenmiştir. 2006 yılına gelindiğinde ise en düşük ve en yüksek nemlilik değerlerinin 0.36 ve 0.30 olduğu ortalama nemlilik değerinin ise -0.17 olarak belirlenmiştir. 1998 yılında ise en düşük ve en yüksek nemlilik 
değerleri -0.38 ve 0.26 ortalama nemlilik ise 0.18 dir. 2016, 2006, 1998 ve 1992 y1llar1 yüzey nemlilik dağılımları karşılaştırıldığında 1992 y1lındaki en yüksek (0.25) ve ortalama (0.20) sıcaklık değerlerinin diğer yıllara göre oldukça düşük olduğu gözlemlenmiştir. Bunun başlıca nedeni barajın yapımından itibaren baraj gölününde etkisi ile bölgenin nemliliğinin artmasıdır (Tablo 5).

Tablo 5: Normalleştirilmiş nem fark indeksi (NDMI) değerlerine ait istatistikler

\begin{tabular}{|l|l|l|l|l|}
\hline \multirow{2}{*}{ Y1llar } & \multicolumn{4}{|l|}{ Normalleştirilmiş nem fark indeksi (NDMI) } \\
\cline { 2 - 5 } & Minimum & Maksimum & Ortalama & $\begin{array}{l}\text { Standart } \\
\text { Sapma }\end{array}$ \\
\hline 2016 & -0.11 & 0.40 & 0.00 & 0.08 \\
\hline 2006 & -0.36 & 0.30 & -0.17 & 0.14 \\
\hline 1998 & -0.38 & 0.26 & -0.18 & 0.15 \\
\hline 1992 & -0.34 & 0.25 & -0.20 & 0.12 \\
\hline
\end{tabular}

1992, 1998, 2006 ve 2016 yıllarında meydana gelen bitki alanları, yüzey nemliliği ve yüzey sıcaklık dağılımları arasındaki ilişki rastlantısal olarak seçilmiş 500 noktada eşit aralıklı ve oran ölçekte ilişkinin ölçülmesi Pearson korelasyon katsayısı kullanılarak test edilmiştir (Şekil 10).

1992, 1998, 2006 ve 2016 y1lları yüzey sicaklıkları arasındaki korelasyonlara bakıldığında 2016 ve 1992 yıllarındaki korelasyonun $0.672,2016$ ve 1998 y1llarındaki korelasyonun 0.831, 2016 ve 2006 yıllarındaki korelasyonun 0.898 olduğu gözlemlenmiş olup bu korelasyon değerleri 1992 y1lından 2016 y1lına kadar yüzey sıcaklığındaki değişimi göstermektedir. Ayrıca, 2006 ve 1998 yıllarındaki korelasyonun 0.893, 2006 ve 1992 yıllarındaki korelasyonun 0.744, 1998 ve 1992 y1llarındaki korelasyonun 0.804 olduğu gözlemlenmiştir. Elde edilen sonuçlara göre yüzey sicaklığındaki en az değişimin 2016 ve 2006 yılları arasında en fazla değişimin ise 2016 ve 1992 yılları arasında olduğu sonucuna varılmıştır.

1992, 1998, 2006 ve 2016 yıllarına ait SAVI değerleri arasındaki korelasyonlara bakıldığında 2016 ve 1992 yıllarındaki korelasyonun $0.482, \quad 2016$ ve 1998 yıllarındaki korelasyonun 0.622, 2016 ve 2006 y1llarındaki korelasyonun 0.687 olduğu gözlemlenmiş olup bu korelasyon değerleri 1992 yılından 2016 y1lına kadar bölgedeki bitki örtüsü miktarındaki değişimi göstermektedir. Ayrıca, 2006 ve 1998 y1llarındaki korelasyonun 0.655, 2006 ve 1992 yıllarındaki korelasyonun 0.482, 1998 ve 1992 y1llarındaki korelasyonun 0.651 olduğu gözlemlenmiştir. Elde edilen sonuçlara göre bitki örtüsü miktarında en fazla değişim 1992 ve 2016 yılları arasında en az değişim ise 2006 ve 2016 yılları arasındadır.

1992 ve 2016 y1lları arasındaki NDMI değerleri arasındaki korelasyonlara bakıldığında 2016 ve 1992 yıllarındaki korelasyonun 0.306, 2016 ve 1998 y1llarındaki korelasyonun 0.417, 2016 ve 2006 yıllarındaki korelasyonun 0.464 olduğu gözlemlenmiş olup bu korelasyon değerleri 1992 yılından 2016 yılına kadar bölgedeki nemlilik miktarındaki değişimi göstermektedir. Ayrıca, 2006 ve 1998 y1llarındaki korelasyonun 0.799, 2006 ve 1992 y1llarındaki korelasyonun 0.764, 1998 ve 1992 yıllarındaki korelasyonun 0.812 olduğu gözlemlenmiştir. Elde edilen sonuçlara göre nemlilik miktarında en fazla değişimin 1992 ve 2016 yılları arsında en az değişimin ise 1992 ve 1998 yılları arasındadır. 


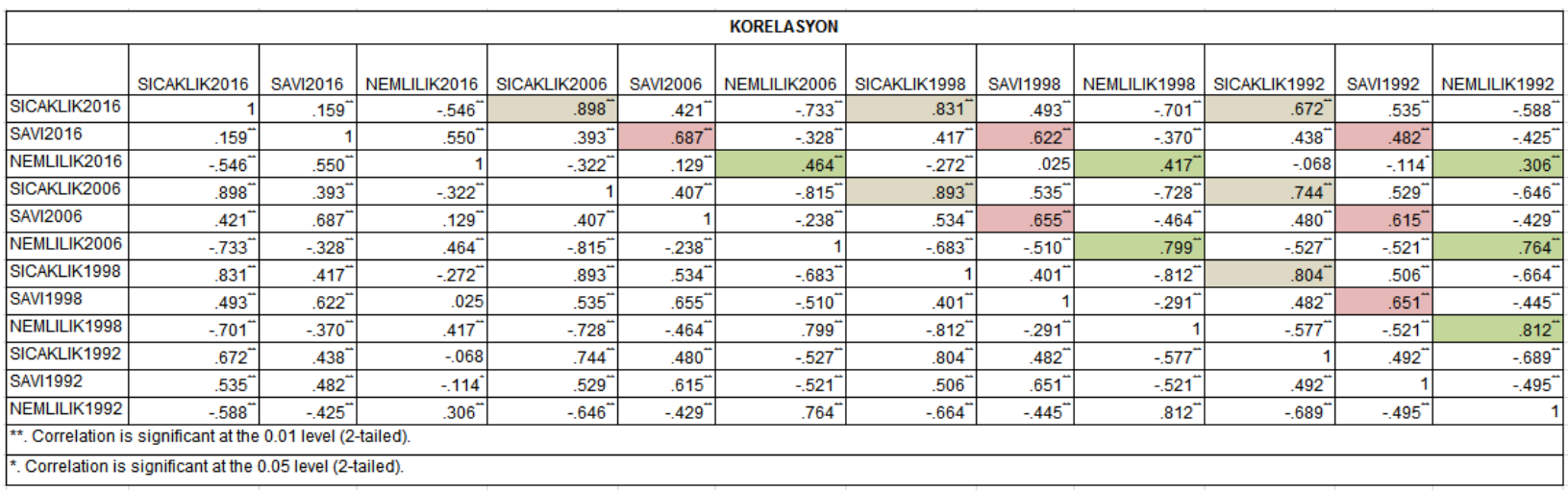

Şekil 10:Rrastlantısal olarak seçilmiş 500 noktada eşit aralıklı ve oran ölçekte yüzey sıcaklık dağılımı SAVI ve NDMI aralarındaki ilişkinin ölçülmesi Pearson korelasyon katsayısı

\section{SONUC}

Atatürk Barajının yapılması ile birlikte 1992 ve 2016 yılları arasında bölgenin yüzey sıcaklık, bitki örtüsü ve nemlilik dağılımında farklılıklar olduğu gözlemlenmiştir. 1992 ve 2016 yılları arasındaki yüzey sıcaklık değerlerinin artmasının en önemli nedenlerinden birisi baraj gölününde etkisi ile bölge havsının ılımanlaşmasıdır. 1992 - 2016 yılları arasında, nemlilik miktarında en fazla değişimin başlıca nedeni barajın yapımından itibaren baraj gölününde etkisi ile bölgenin nemliliğinin artmasıdır. Bitki örtüsünde 1992 ve 2016 yılları arasındaki artışın başlıca nedeninin baraj gölü çevresindeki tarım alanlarının yoğunluğunun artması olarak yorumlanabilinir.

Elde edilen sonuçlara göre yüzey sıcaklığındak en az değişimin 2016 - 2006 yılları arasında en fazla değişimin ise 2016 1992 yılları arasında, bitki örtüsü miktarında en fazla değişimin 1992 - 2016 yılları en az değişimin ise 2006 - 2016 yılları arasında, nemlilik miktarında en fazla değişimin 1992 2016 yılları arsında en az değişimin ise 1992 ve 1998 yılları arasında olduğu sonucuna varılmıştır.

\section{KAYNAKÇA}

Bacanl1, G. ve Tuğrul, A. T. (2016) Baraj göllerinin iklimsel etkisi ve Vali Recep Yazıcıŏlu Gökpınar baraj gölü örneği, Pamukkale Univ Muh Bilim Derg, 22(3), 154159, 2016.
Bayrakdar, C. (2004) Doğal Çevre Sorunları Yaratan Hatalı Arazi Kullanımından Biri: Barajlar. Mersin Üniversitesi Çevre Topluluğu 6. Ulusal Çevre Sorunları Öğrenci Yaklaşımları Sempozyumu Bildiriler Kitabı.

Bulut H., Yeşilata B., Yeşilnacar M.İ. (2006) Atatürk baraj gölünün bölge iklimi üzerine etkisinin trend analizi ile tespiti. GAP V. Mühendislik Kongresi, Şanlıurfa, Türkiye, 2628 Nisan 2006.

Chander, G., Markham, B. (2003) Revised Landsat-5 TM Radiometric Calibration Procedures and Postcalibration Dynamic Ranges. IEEE Transactions On Geoscience And Remote Sensing, 41, (11), 2003.

Colwell, J. E. (1974) Vegetation canopy reflectance, Remote Sens. Environ. 3:175183.

Cubukcu, K.M. (2015). Planlamada ve Coğrafyada Temel İstatistik ve Mekansal İstatistik. Nobel Yayınevi, Ankara.

Elvidge, C. D., and Lyon, R. J. P. (1985) Influence of rock-soil spectral variation on assessment of green biomass, Remote Sens. Environ. 17:265-279.

\section{DSI}

http://web.archive.org/web/20151123030113/ http://www.dsi.gov.tr/projeler/ataturk-baraji. Erişim tarihi: 18 Aralık 2016.

Güldal V., Ağıralioğlu N. (1994) Baraj haznelerinin iklime etkisi: Keban barajı. Su ve Toprak Kaynaklarını Geliştirme Konferansı, Ankara, Türkiye, 12-14 Nisan 1994. 
Hardisky, M.A., Klemas, V., Smart, R.M (1983) The influence of soil salinity, growth form, and leaf moisture on the spectral radiance of Spartina alterniflora canopies Photogrammetric Engineering and Remote Sensing, 49 (1983), pp. 77-83

Huete, A.R., (1988) A soil-adjusted vegetation index (SAVI). Remote Sensing of Environment, vol. 25, issue 3, pp. 259-309. DOI: $10.1016 / 0034-4257(88) 90106-X$

Mendenhall, W., Reinmuth, J.E., Beaver, R. ve D. Duhan (1986) Statistics for Management and Economics, 5th edition. Duxbury Press.

NASA (2011) Landsat 7 Science Data Users Handbook. Landsat Project Science Office at NASA Goddard Space Flight Centre, Greenbelt, 186 (http://landsathandbook.gsfc.nasa.gov)

Sönmez M. E. (2012) Barajların Mekân Üzerindeki Olumsuz Etkileri ve Türkiye'den Örnekler Gaziantep Üniversitesi Sosyal Bilimler Dergisi (http://sbe.gantep.edu.tr) 2012 11(1):213 -231 ISSN: 1303-0094

Kadığlu M, Satılmış S, Özgüler H, (1994) Büyük su yapılarının çevre iklimine etkisi. Su ve Toprak Kaynaklarının Geliştirilmesi Konferans1, Ankara, Türkiye, 12-14 Nisan 1994

Nagarajan, R. (2000) Environmental impact analysis of Dudhganga Dam in India - a multi-temporal remote sensing approach, International Journal of Remote Sensing, 21:3, 483-497, DOI: $10.1080 / 014311600210704$

Tucker, C. J. (1979) Red and photographic infrared linear combinations for monitoring vegetation, Remote Sens. Environ. 8:127-150.

USGS., (2013) Landsat 8 (L8) Data Users Handbook Version 1.0. Available online: http://landsat.usgs.gov//18handbook.php

Yeşilata, B., Bulut, H., Yeşilnaçar, M.I. (2004) GAP bölgesinde Sicaklık ve Nem Parametrelerindeki Baraj Gölü Kaynaklı
Değişim Trendinin Araştırılması. Tesisat Mühendisliği Dergisi. 83, 21-31

Yeşilnaçar, M. I ve Gülşen, H. (1999) Şanlıurfa ve Çevresinin İklim Özellikleri ve Atatürk Barajının Yöre İklimi zerine Etkileri 52. Türkiye Jeoloji Kurultayı Bildiriler Kitab1, 10-12 Mayıs 1999, Ankara 